\title{
Effects of neuritin on the differentiation of bone marrow-derived mesenchymal stem cells into neuron-like cells
}

\author{
JINGLING ZHU $^{1 *}$, PINGPING MENG $^{1 *}$, QIAN WANG $^{1 *}$, HAIYAN WANG $^{1}$, JINLI ZHANG $^{1}$, \\ YUANYUAN LI ${ }^{1}$, DONGZHENG LI ${ }^{1}$, XIAOHUA TAN ${ }^{2}$, LEI YANG ${ }^{2}$ and JIN HUANG ${ }^{1}$ \\ ${ }^{1}$ The Key Laboratory of Xinjiang Endemic and Ethnic Diseases and Department of Biochemistry, \\ Shihezi University School of Medicine, Shihezi, Xinjiang 832002; ${ }^{2}$ Occupational and Environmental Health, \\ Department of Preventive Medicine, School of Medicine, Hangzhou Normal University, \\ Hangzhou, Zhejiang 310036, P.R. China
}

Received February 17, 2016; Accepted February 16, 2017

DOI: $10.3892 / \mathrm{mmr} .2017 .6987$

\begin{abstract}
While the neurotrophic factor neuritin is known to be involved in neurodevelopment, the effects of this compound on cell differentiation remain unclear. The present study demonstrated that neuritin treatment induced the differentiation of rat bone marrow-derived mesenchymal stem cells (rBM-MSCs) into neuron-like (NL) cells. For these analyses, rBM-MSCs were incubated with $0.5 \mu \mathrm{g} / \mathrm{ml}$ neuritin for $24 \mathrm{~h}$. Following induction, 27\% of the rBM-MSCs exhibited typical NL cell morphologies. Subsequently, NL cells were characterized by examining the expression of neuronal markers and by analysis of cell functions. The findings demonstrated that the NL cells produced by neuritin treatment expressed the neuronal markers neuron-specific enolase and microtubule associate protein 2 , and secreted the neurotransmitter 5-hydroxytryptamine. Furthermore, the NL cells exhibited certain partial neural-electrophysiological
\end{abstract}

Correspondence to: Dr Jin Huang, The Key Laboratory of Xinjiang Endemic and Ethnic Diseases and Department of Biochemistry, Shihezi University School of Medicine, 2 North Rd, Shihezi, Xinjiang 832002, P.R. China

E-mail: huangjin623@163.com

Dr Lei Yang, Occupational and Environmental Health, Department of Preventive Medicine, School of Medicine, Hangzhou Normal University, 58 Haishu Rd Hangzhou, Zhejiang 310036, P.R. China E-mail: 20080009@hznu.edu.cn

*Contributed equally

Abbreviations: bFGF, basic fibroblast growth factor; CM, membrane capacitance; GFAP, glial fibrillary acidic protein; 5-HT, 5-hydroxytryptamine; MAP2, microtubule associated protein-2; NSE, neuron-specific enolase; RP, resting membrane potential; rBM-MSCs, rat bone marrow-mesenchymal stem cells; TLC, thin layer chromatography

Key words: neuritin, neuronal differentiation, mesenchymal stem cells, cell therapy, neuron-like cells, NSE, MAP2, neurodegenerative diseases functions. In conclusion, neuritin treatment may be an effective method for inducing the differentiation of BM-MSCs towards NL cells. This may provide an alternative, potentially complementary tool for disease modeling and the development of cell-based therapies.

\section{Introduction}

The directional differentiation of stem cells provides an important approach to cell therapy for the treatment of neurological diseases $(1,2)$. However, two primary issues remain to be resolved: The determination of appropriate seed cells and the identification of efficient inducers. The multi-directional differentiation potential of mesenchymal stem cells (MSCs), which has been well characterized by in vitro culture and auto-transplantation approaches, has resulted in these cells being widely used as seed cells for cell therapy. Meanwhile, the potential usage of neurotrophins as inducers of stem cell differentiation has received considerable attention $(3,4)$. Neuritin (Nrnl or CPG15), a neurotrophic factor that was identified in a study of plasticity-related genes, has been demonstrated to promote neurite growth and the survival of cortical neurons $(5,6)$. While the effects of neuritin on cell differentiation have yet to be reported, results obtained in a previous study suggest that neuritin is involved in this process (7).

In the present study, the effects of neuritin on the directional differentiation of MSCs toward neuron-like (NL) cells were evaluated by analyzing cell morphology, expression levels of neuronal markers, and neuronal functions of rat bone marrow-derived MSCs (rBM-MSCs) treated with recombinant neuritin protein purified from Pichia pastoris (8).

\section{Materials and methods}

Ethics statement. Animal experiments were performed in accordance with the National Institute of Health Guidelines for the Care and Use of Laboratory Animals. Formal approval to conduct the experiments described was obtained from the Animal Subjects Review board of The First Affiliated 
Hospital of Shihezi University School of Medicine (Shihezi, China; permit no.: 2011LL02). All efforts were made to minimize suffering.

Isolation and culturing of rat MSCs. In the present study, male and female Sprague-Dawley rats ( $\mathrm{n}=25$; age, 4-6 weeks; weight, 80-100 g) (provided by the Institute of Epidemiology, Xinjiang Uygur Autonomous Region, Shihezi, China) were housed under standardized laboratory conditions in an air-conditioned room at constant temperature $\left(23 \pm 2^{\circ} \mathrm{C}\right)$ and relative humidity of $45 \pm 5 \%$ on a $12 \mathrm{~h}$ light/dark cycle, with free access to food and water. Rats were sacrificed by cervical dislocation, and the tibias and femurs were isolated under sterile conditions, as previously described $(9,10)$. Both ends of the bone were cut to expose the bone marrow cavity, and bone marrow cells were collected by rinsing with $5 \mathrm{ml} \mathrm{L}$-Dulbecco's Modified Eagle's medium (DMEM; cat. no. SH30022.01; Hyclone; GE Healthcare Life Sciences, Logan, UT, USA) followed by centrifugation at $156 \mathrm{x} \mathrm{g}$ for $10 \mathrm{~min}$ at room temperature. The harvested cells were then seeded in culture dishes at a density of $1 \times 10^{6}$ cells $/ \mathrm{ml}$ in L-DMEM/Nutrient Mixture F12 (cat. no. 12400024; Gibco; Thermo Fisher Scientific, Inc., Waltham, MA, USA) supplemented with $10 \%$ fetal bovine serum (FBS; cat. no. 12478020; Gibco; Thermo Fisher Scientific, Inc.), $100 \mathrm{U} / \mathrm{ml}$ penicillin and $100 \mu \mathrm{g} / \mathrm{ml}$ streptomycin, and cultivated at $37^{\circ} \mathrm{C}$ in a $5 \% \mathrm{CO}_{2}$ incubator for $24 \mathrm{~h}$, following which non-adherent cells were removed. The culture medium was replaced every 3 days until the cells reached $90 \%$ confluency. Cells were then digested by treatment with $1 \mathrm{ml} 0.125 \%$ trypsin (cat. no. 25200072; Gibco; Thermo Fisher Scientific, Inc.) for 5-8 min at $37^{\circ} \mathrm{C}$, mixed with $1 \mathrm{ml} \mathrm{L}$-DMEM, and centrifuged at $156 \mathrm{x}$ g for $10 \mathrm{~min}$ at room temperature. Collected cells were then subcultured at a 1:2 ratio. The third passage of MSCs were used for in vitro experiments.

Neuronal induction. rBM-MSCs $\left(4 \times 10^{3}\right.$ cells $\left./ \mathrm{ml}\right)$ were initially maintained in DMEM containing 10\% FBS. The medium was replaced with pre-induction medium consisting of DMEM supplemented with 10\% FBS $24 \mathrm{~h}$ prior to induction, and $20 \mathrm{ng} / \mathrm{ml}$ basic fibroblast growth factor (bFGF; cat. no. 13256029; Invitrogen; Thermo Fisher Scientific, Inc.). To initiate neuronal differentiation, the pre-induction medium was removed, and cells were washed with PBS and incubated in neuronal induction medium, which consisted of DMEM supplemented with $20 \mathrm{ng} / \mathrm{ml} \mathrm{bFGF}, 2 \%$ B-27 supplement (cat. no. 0050129SA; Invitrogen; Thermo Fisher Scientific, Inc.), and $0.5-2.0 \mu \mathrm{g} / \mathrm{ml}$ neuritin (derived from Pichia pastoris) (8). Cells were incubated in media containing His-tagged protein (cat. no. bs-0287P; Bioss, Beijing, China) and 2\% B-27 supplement wasused as a negative control.

Optimization of the induction conditions for MSC differentiation. The number of cells exhibiting NL morphology was counted in five randomly selected fields (minimum of 100 cells/field) at $0,6,24,48$ and $72 \mathrm{~h}$ post-induction. The percentage of positive NL cells was calculated as follows: positive NL cells $(\%)=($ number of NL cells/total number of cells) $\times 100 \%$.

To enumerate viable cells, trypan blue $(0.4 \%)$ was added to cell suspensions $\left(4 \times 10^{3}\right.$ cells $\left./ \mathrm{ml}\right)$ at a ratio of $1: 9(\mathrm{v} / \mathrm{v})$. Cells that absorbed trypan blue were considered non-viable, and viable cells were counted using a hemocytometer (cat. no. 02270113; QiuJing, Shanghai, China) at a magnification of $x 400$ under a light microscope within 3 min of dying. The total cell numbers of 4 large fields of the hemocytometer were counted according to the principle that cells above or to the left of the boundary line were recorded. The percentage of viable cells was calculated as follows: viable cells $(\%)=[1.00$-(number of blue cells/total cell numbers)] x100\%.

Analysis of MSC phenotypes by immunofluorescence microscopy. Slides with MSCs $\left(2.5 \times 10^{4}\right.$ cells $\left./ \mathrm{ml}\right)$ from the third passage were rinsed three times with PBS and fixed with PBS containing $4 \%$ paraformaldehyde for $30 \mathrm{~min}$ at room temperature. The following operations were performed using a wet box: 5 min washing with PBS, repeated 3 times, and slides containing MSCs were incubated in blocking solution containing 10\% goat serum (cat. no. ZLI-9022; OriGene Technologies, Inc., Beijing, China) for $30 \mathrm{~min}$ at room temperature. Cells were subsequently incubated overnight at $4^{\circ} \mathrm{C}$ with the following primary antibodies: CD29 (1:100; cat. no. bs-20630R; Bioss), CD90 (1:100; cat. no. bs-0778R; Bioss), CD34 (1:100; cat. no. bs-0646R; Bioss), CD44 (1:100; cat. no. bs-0521R; Bioss), or CD45 (1:100; cat. no. bs-0522R; Bioss). PBS was utilized as a negative control. Subsequently, cells were incubated with fluorescein isothiocyanate (FITC) -labeled goat anti-rabbit IgG (1:100; cat. no. ab6717; Abcam, Cambridge, UK) for $2 \mathrm{~h}$ at $25^{\circ} \mathrm{C}$ in the dark, washed with PBS, and observed in five randomly selected fields (minimum 100 cells/field) by fluorescence microscopy (Carl Zeiss AG, Oberkochen, Germany).

Detection of neural markers by immunofluorescence microscopy. rBM-MSCs $\left(2.5 \times 10^{4}\right.$ cells $\left./ \mathrm{ml}\right)$ were grown on coverslips, as described, and treated with different concentrations $(0.5,1,1.5$ and $2.0 \mu \mathrm{g} / \mathrm{ml})$ of recombinant neuritin for $24 \mathrm{~h}$. Slides with MSCs were rinsed with $37^{\circ} \mathrm{C}$ PBS $(\mathrm{pH}=7.2)$ three times, each time for $3 \mathrm{~min}$, fixed by incubating in cold $\left(-20^{\circ} \mathrm{C}\right)$ acetone for $15 \mathrm{~min}$, and then washed with PBS and blocked as described above. Cells were incubated overnight at $4^{\circ} \mathrm{C}$ with the following primary antibodies: Anti-neuron-specific enolase (NSE; 1:500; cat. no. ab217778; Abcam), anti-microtubule associate protein 2 (MAP2; 1:500; cat. no. ab32454; Abcam), or anti-glial fibrillary acidic protein (GFAP; 1:750; cat. no. ab7260; Abcam). PBS was utilized as a negative control. Cells were subsequently treated with a FITC-labeled goat anti-rabbit secondary antibody (1:100; cat. no. ab6717; Abcam) for $1 \mathrm{~h}$ at $25^{\circ} \mathrm{C}$ in the dark, washed with PBS, and observed in five randomly selected fields (minimum 100 cells/field) under a fluorescence microscope (Carl Zeiss AG).

Western blot analysis. $\mathrm{rBM}-\mathrm{MSCs}\left(8 \times 10^{6} \mathrm{cells} / \mathrm{ml}\right)$ were treated with $0.5 \mu \mathrm{g} / \mathrm{ml}$ neuritin for $24 \mathrm{~h}$. The cells were rinsed twice in ice-cold PBS (pH 7.5) and lysed with radioimmunoprecipitation assay buffer (cat. no. R0010; Solarbio, China) containing $1 \mathrm{mM}$ PMSF (cat. no. P0100; Beijing Solarbio Science and Technology Co., Ltd, Beijing, China), and placed on ice for $30 \mathrm{~min}$. The cell lysates were centrifuged at $5,000 \mathrm{x} \mathrm{g}$ for $10 \mathrm{~min}$ at $4^{\circ} \mathrm{C}$. The extractive proteins were then separated by $10 \%$ SDS-PAGE and transferred to nitrocellulose membranes. Membranes were blocked by incubating in Tris-buffered saline 

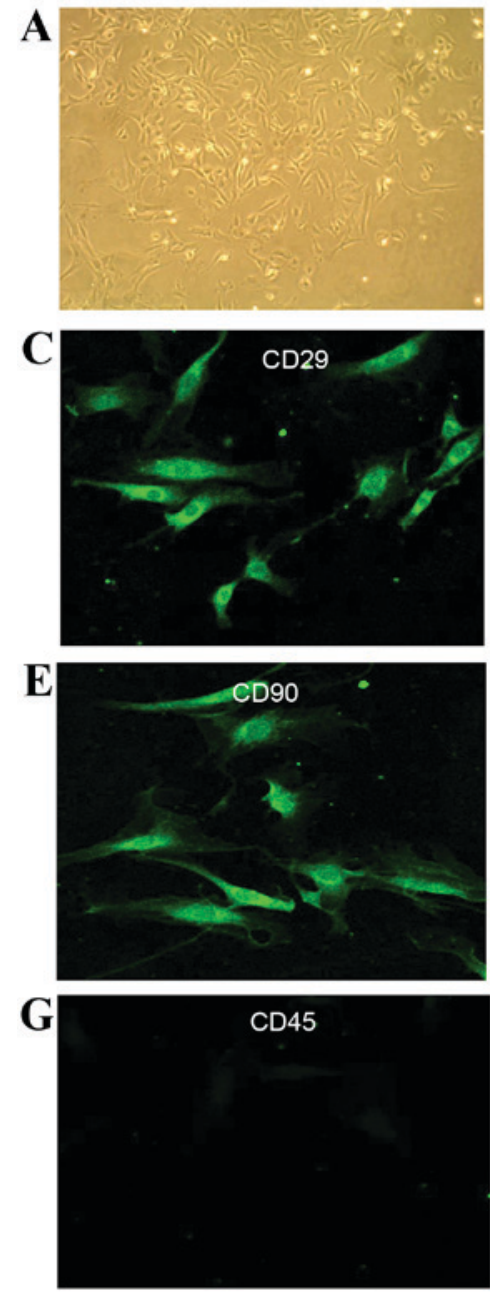
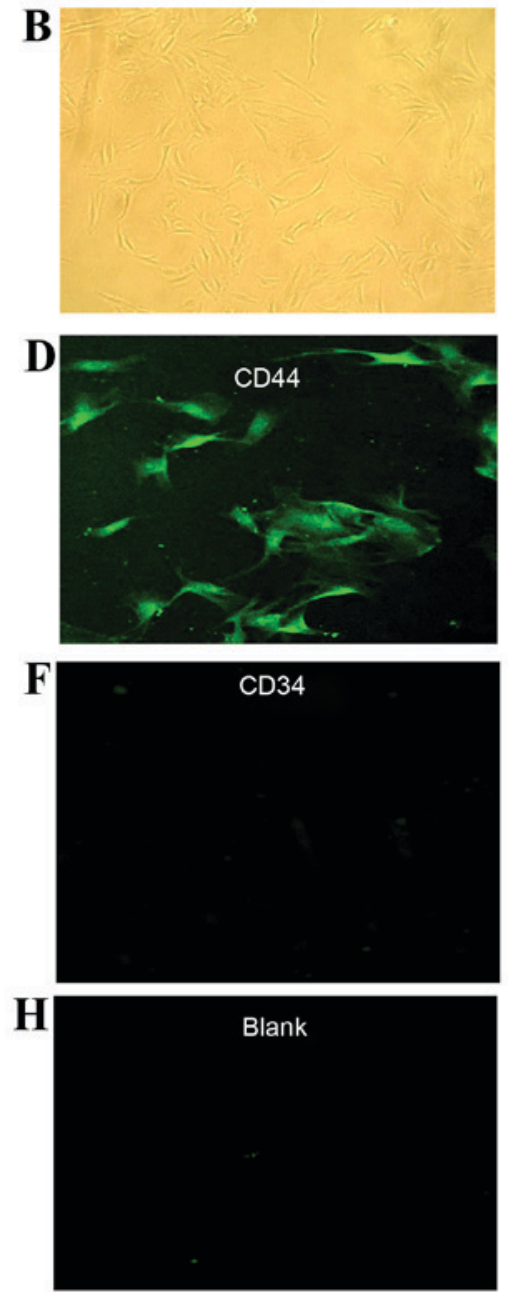

Figure 1. Characterization of rBM-MSCs. (A) Primary cultured rBM-MSCs were spindle or polygonal in shape and formed colonies following 96 h incubation. (B) Following passage three, cells exhibited a fibroblast-like morphology (x100 magnification). Indirect immunofluorescence analysis indicated positive expression of the cell surface markers (C) CD29, (D) CD44 and (E) CD90, but not (F) CD34 and (G) CD45. (H) Control cells (magnification, x200). rBM-MSCs, rat bone marrow-derived mesenchymal stem cells.

containing $0.05 \%$ Tween-20 and 5\% nonfat dry milk for $1 \mathrm{~h}$ at room temperature, and then probed with MAP2 $(1: 1,000)$, NSE $(1: 1,000)$, and GFAP-specific (1:500) primary antibodies diluted in blocking buffer overnight at $4^{\circ} \mathrm{C}$. Subsequently, the membranes were incubated with a horseradish peroxidase-conjugated secondary antibody (goat anti-mouse; 1:50,000; cat. no. ZB-2301; OriGene Technologies, Inc.) for $1 \mathrm{~h}$ at room temperature, and proteins were visualized by enhanced chemiluminescence (cat. no. WBKLS0500; EMD Millipore, Billerica, MA, USA). Detection of $\beta$-actin (mouse anti- $\beta$-actin; cat. no. sc-47778; $1: 1,500$; Santa Cruz Biotechnology, Inc., Dallas, TX, USA) was performed as an internal loading control.

Thin-layer chromatography (TLC). The induced cell culture $\left(4 \times 10^{3}\right.$ cells $\left./ \mathrm{ml}\right)$ was blast chilled and ground into powder (Freeze Dryer Series; SIM International Group Co., Ltd., Beijing, China). The powder was dissolved with $1 \mathrm{ml}$ carbinol and uninduced cell culture powder was used as control. The dissolved powder samples, as well as serotonin (used as a standard), were spotted on a thin-layer chromatogram plate and treated with an n-butyl alcohol-acetic acid- $\mathrm{ddH}_{2} \mathrm{O}$ solution
(4:1:5). The chromatograph was then sprayed with the color developing agent $\mathrm{O}$-phthaldialdehyde (1 g in 100 mlethanol) and incubated at $110^{\circ} \mathrm{C}$ for $20 \mathrm{~min}$.

Electrophysiological recordings. Conventional whole-cell recordings were performed as previously described (11). Briefly, cells exhibiting neuron-like morphologies were selected for analysis, while uninduced MSCs were used as a control. Recording pipettes were pulled from borosilicate glass capillaries with a filament using a Sutter Instruments P-97 puller (Sutter Instrument Company, Novato, CA, USA). The pipette had a resistance of $\sim 5 \mathrm{M} \Omega$ uponbeing filled with an internal solution comprised as follows: $150 \mathrm{mM} \mathrm{NaCl}$, $5.0 \mathrm{mM} \mathrm{KCl}, 2.5 \mathrm{mM} \mathrm{CaCl}_{2}, 1.0 \mathrm{mM} \mathrm{MgCl}_{2}, 5.0 \mathrm{mM}$ glucose and $10 \mathrm{mM}$ 3-[4-(2-hydroxyethyl)-1-piperazinyl] propanesulfonic acid. The passive membrane properties and ion channel of the cell samples were determined by stimulating the cells with $20 \mathrm{mV}$ hyperpolarizing steps in a voltage clamp. The holding membrane potential was $-60 \mathrm{mV}$. The membrane currents or voltage signals were low-pass filtered at $10 \mathrm{kHz}$ (-3 dB) using an Axon 700B amplifier (Axon Instruments; Molecular Devices LLC, Sunnyvale, CA, USA), and were 
digitized (Axon Digidata 1440; Axon Instruments; Molecular Devices LLC) and analyzed using a pCLAMP (pClamp 10.2; Axon Instruments; Molecular Devices LLC). All experiments were performed at room temperature.

Statistical analysis. The results are presented as the mean \pm standard deviation. Repeated measures analysis of variance and the least significant difference (LSD) post hoc test, and independent sample Student's t-tests, were utilized to detect differences between results. SPSS 20.0 software (IBM SPSS, Inc., Armonk, NY, USA) was utilized for all statistical analyses. $\mathrm{P}<0.05$ was considered to indicate a statistically significant difference.

\section{Results}

Characterization of cultured MSCs. Isolated rBM-MSCs were cultured and subjected to the whole-cell adherence screening method as described previously (12). Cell colonies were observed $96 \mathrm{~h}$ following primary culture, and the cells were spindled or polygonal in shape (Fig. 1A). Following three passages, the morphology of the cells was fibroblast-like, and was consistent with that of MSCs (Fig. 1B). Indirect immunofluorescence analysis detected the expression of the MSC-specific surface antigens CD29, CD44, and CD90 in P3 cells (Fig. 1C-E, respectively), but not the hematopoietic stem cell-specific surface antigens CD34 and CD45 (Fig. 1F and G, respectively), which appeared the same as the blank control (Fig. 1H). These findings indicated that the P3 cultures were comprised of MSCs.

Optimization of cell differentiation conditions. No significant change in the number of positive NL cells in the control group was detected at any time point tested (Fig. 2A). By contrast, the number of positive NL cells in each of the neuritin groups increased steadily with time, and were significantly increased at $6 \mathrm{~h}$ onwards compared with present at the $0 \mathrm{~h}$ time point $(\mathrm{P}<0.05$; Fig. 2A). Notably, the number of positive cells in each neuritin treatment group was significantly higher at $24 \mathrm{~h}$ than at any other time point $(\mathrm{P}<0.05$; Fig. $2 \mathrm{~A})$.

There was a dose-dependent increase in the number of NL cells at neuritin concentrations between 0 and $0.5 \mu \mathrm{g} / \mathrm{ml}$ (Fig. 2B). However, following $24 \mathrm{~h}$ induction, the number of positive cells was significantly higher in the $0.5 \mu \mathrm{g} / \mathrm{ml}$ neuritin group than in the other treatment groups $(\mathrm{P}<0.05$; Fig. $2 \mathrm{~B})$. Therefore, $0.5 \mu \mathrm{g} / \mathrm{ml}$ neuritin was utilized as the induction concentration for further experiments.

To exclude the possibility that treatment with the inducer resultedin cytotoxic effects on the rBM-MSCs, the viability of treated cells was examined by trypan blue staining. The viability of the cells induced with $0.5 \mu \mathrm{g} / \mathrm{ml}$ neuritin was significantly higher than that of the control group at 24, 48 and $72 \mathrm{~h}(\mathrm{P}<0.05$; Fig. 2C), but not at the $6 \mathrm{~h}$ time point (Fig. 2C).

Together, these results indicated that optimal production of NL cells was achieved by treatment of rBM-MSCs with $0.5 \mu \mathrm{g} / \mathrm{ml}$ neuritin for $24 \mathrm{~h}$.

Characterization of the morphology and the expression patterns of neuron-specific proteins in MSCs treated with neuritin. Cells in the control group exhibited a fibroblast-like
Table I. Comparison of membrane properties between the control group and NL cells following induction.

\begin{tabular}{lll}
\hline Group & \multicolumn{1}{c}{ CM, pF } & RP, mV \\
\hline Control $(n=6)$ & $15.55 \pm 2.40$ & $-22.00 \pm 2.95$ \\
NL cells $(n=8)$ & $31.56 \pm 4.53^{\text {a }}$ & $-49.01 \pm 4.76^{\mathrm{a}}$ \\
\hline
\end{tabular}

CM, membrane capacitance; RP, resting membrane potential; NL cells, neuron-like cells; $\mathrm{pF}$, picofarads; $\mathrm{mV}$, millivolts. ${ }^{\mathrm{a}} \mathrm{P}<0.01$ vs. control.
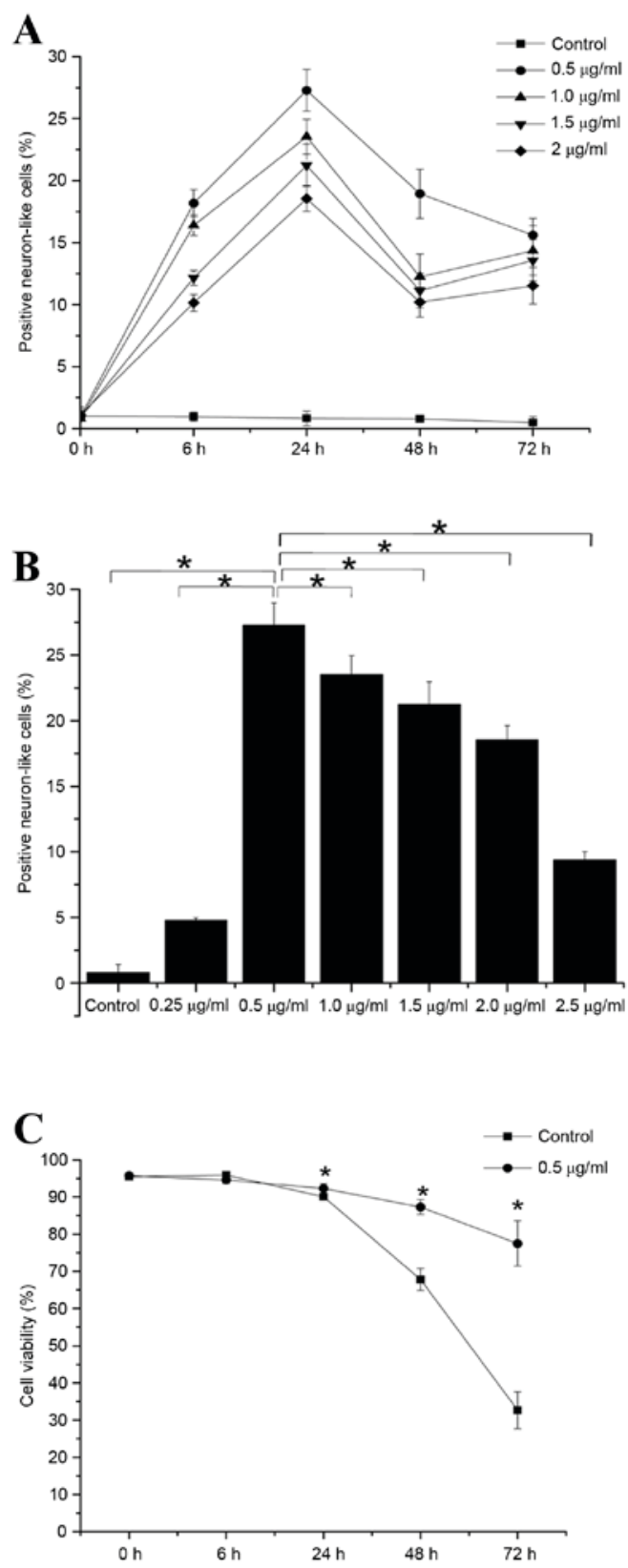

Figure 2. Optimization of the differentiation conditions. (A) The formation of neuron-like MSCs was observed in the neuritin treatment groups by phase contrast microscopy. All groups achieved the highest number of positive MSCs at $24 \mathrm{~h}$ post-induction. These values were significantly different from those of other time points $(\mathrm{P}<0.05)$. (B) The number of neuron-like MSCs in each neuritin treatment group $24 \mathrm{~h}$ post-induction. ${ }^{*} \mathrm{P}<0.05 \mathrm{vs} .0 .5 \mu \mathrm{g} / \mathrm{ml}$ neuritin group. (C) Analysis of MSC cell viability in the $0.5 \mu \mathrm{g} / \mathrm{ml}$ neuritin induction group by trypan blue staining. ${ }^{*} \mathrm{P}<0.05$ vs. control. MSCs, mesenchymal stem cells. 

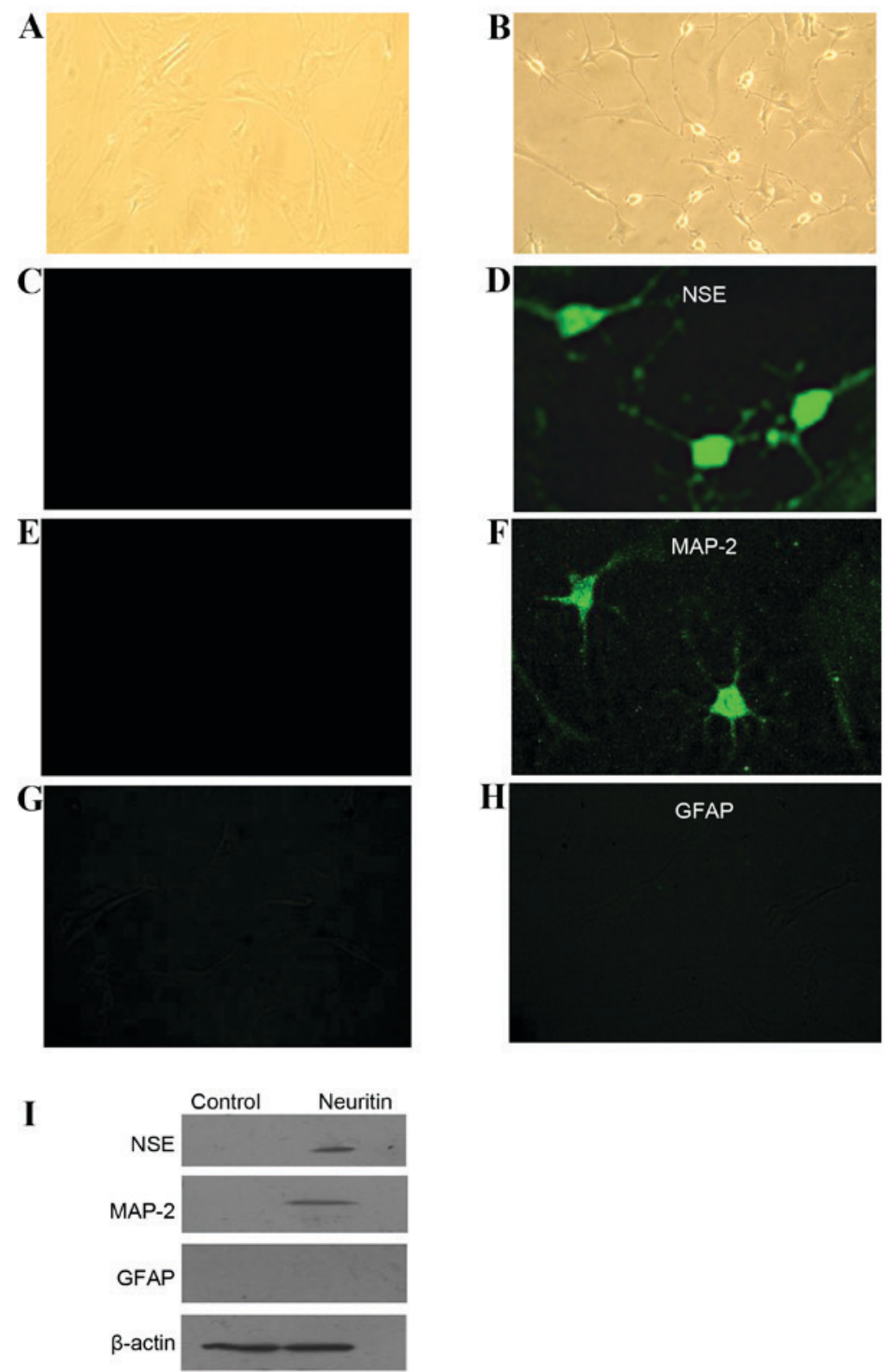

Figure 3. Characterization of the morphology and the expression patterns of neuron-specific proteins in rBM-MSCs treated with neuritin. While cells in the (A) control group were similar to fibroblasts, (B) differentiated rBM-MSCs exhibited neuron-like cell morphologies. The cell body condensed and became refractile, and the cells composed a network with bipolar or multipolar long processes (magnification, $\mathrm{x} 200$ ). (C-H) Indirect immunofluorescence was performed to detect the expression (C and D) NSE, (E and F) MAP2 and (G and H) GFAP following induction with neuritin (magnification, x400). (I) Similar results were obtained by western blot analysis of NSE, MAP2, and GFAP expression in neuritin-induced and control cells. rBM-MSCs, rat bone marrow-derived mesenchymal stem cells; NSE, neuron-specific enolase; MAP2, microtubule associated protein-2; GFAP, glial fibrillary acidic protein.

morphology (Fig. 3A). Following treatment with $0.5 \mu \mathrm{g} / \mathrm{ml}$ neuritin for $24 \mathrm{~h}$, however, $27 \%$ of the rBM-MSCs exhibited typical NL cell morphologies (13) with long processes (Fig. 3B). The cell body condensed and became refractile, and the cells formed a network with bipolar or multipolar neurites.

To confirm that the NL cells were of a neuronal lineage, indirect immunofluorescence was utilized to examine the expression of neuron-specific proteins. The mature neural marker NSE (Fig. 3C and D) and the dendritic marker MAP2 (Fig. 3E and F) were expressed in the NL cells but not in the control cells. Meanwhile, neither the neuritin-treated nor the control cells exhibited positive expression of the astrocyte marker GFAP (Fig. 3G and H). Similar findings were obtained by western blot analysis (Fig. 3I). These results indicated that
rBM-MSCs acquired the cellular characteristics of cells in the neuronal lineage, but not of astrocytes, following neuritin treatment.

Characterization of the neuronal functions of NL cells. To establish whether the NL cells produced by neuritin treatment exhibited neuronal functions, the electrophysiological properties of these cells were analyzed by whole-cell patch clamp recording. The membrane capacitance $(\mathrm{CM})$ and resting membrane potential (RP) of the NL and control cells were $31.56 \pm 4.53 \mathrm{pF}(\mathrm{n}=8)$ and $15.55 \pm 2.40 \mathrm{pF}(\mathrm{n}=6)$, and $-49.01 \pm 4.76 \mathrm{mV}(\mathrm{n}=8)$ and $-22.00 \pm 2.95 \mathrm{mV}(\mathrm{n}=6)$, respectively; and these differences were statistically significant $(\mathrm{P}<0.01$; Table I). The ionic current of the neuritin-treated 
and control cells were then measured using the voltage clamp method. No apparent channel opening was observed in the control cells (Fig. 4A), but an outward delayed rectifying current was detected in the treatment group with increasing voltage (Fig. 4B and C), which may indicate the presence of a voltage-dependent $\mathrm{K}^{+}$current. These results suggested that the $\mathrm{K}^{+}$channel maybe observed concomitantly with morphological changes and the expression of certain neuron-specific protein markers. Lastly, TLC was utilized to examine whether the neurotransmitter 5-hydroxytryptamine (5-HT) was secreted from neuritin-induced MSCs. A 5-HT-specific signal was detected in the neuritin but not the control sample (Fig. 4D).

\section{Discussion}

The incidence of neurodegenerative diseases hasincreased with aging in the population, but effective methods are still lacking for treating these diseases. While nerve cell therapy is currently considered one of the most promising solutions to these diseases, there are several barriers including cell source deficiency, immunological rejection, safety and ethical conflicts, which continue to limit the application of this treatment. However, previous studies have reported that stem cells exhibit the potential to differentiate into nerve cells, which maybe advantageous for nerve cell transplantation therapy $(14,15)$.

MSCs are progenitor cells with multilineage differentiation potential. These cells are capable of differentiating into osteoblasts, chondrocytes and adipocytes from the mesoderm (16) and into neurons from the ectoderm (17).Furthermore, due to several unique advantages including good self-renewal capability, proliferating well in in vitro culture, adequate resources, convenient access and the capacity to be auto-transplanted, the rarity of immunological rejection and the lack of ethical complications, MSCs are becoming an important option for use as seed cells for cell replacement therapy.

While the bone marrow MSC content is limited (18), the present studyovercame this obstacle by adherent culturing of rBM-MSCs in vitro. Following the third passage, the cells exhibited a typical MSC morphology (19) and expressed the MSC-specific surface antigens CD29, CD44 and CD90 (20), but not the hematopoietic stem cell-specific surface antigens CD34 and CD45 (21). These results therefore excluded the possibility that the cells were of hematopoietic origin.

Differentiation is a complex process involving the activity of multiple factors. Combination induction is currently the most extensively applied approach for inducing the differentiation of MSCs into neurons (22). In accordance with the Woodbury method (23), in the present study MSCs were induced with neuritin following pre-induction with bFGF. The optimal induction condition was established through detection of the number of NL cells combined with the cell viability by which cytotoxicity caused by the inducer was excluded $(24,25)$, and it was determined that exposure to $0.5 \mu \mathrm{g} / \mathrm{ml}$ neuritin for $24 \mathrm{~h}$ comprised the optimal conditions for stimulating the differentiation of MSCs into NL cells. Indeed, under these conditions, MSCs effectively differentiated into typical NL cells that contained neurites. The NL cells were then characterized by examining the expression levels of specific neuronal markers and by observing certain physiological functions. Immunofluorescence and western blot analyses
A

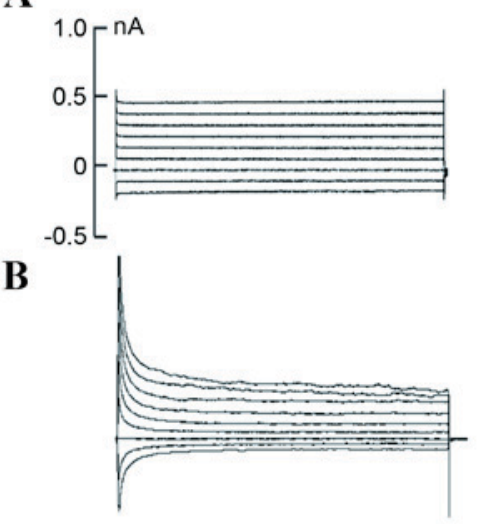

C

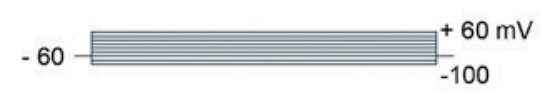

D

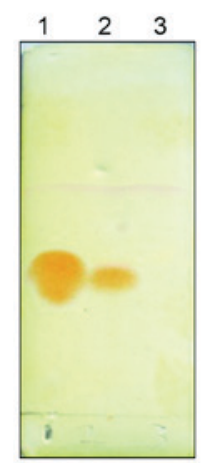

Figure 4. Characterization of the neuronal function of neuritin-treated rBM-MSCs. (A) No apparent ion channel opening was observed in the control cells by whole-cell recording under voltage clamp conditions. (B) The outward delayed rectifier $\mathrm{K}^{+}$current was detected in neuritin-induced cells. (C) Cells were clamped at $-60 \mathrm{mV}$ with a depolarizing step from $-100 \mathrm{mV}$ to $60 \mathrm{mV}$, at increments of $20 \mathrm{mV}$. (D) Thin-layer chromatography was conducted to detect the expression and secretion of the neurotransmitter 5-HT from neuritin-induced rBM-MSCs. Specific dots appeared at the expected site for 5-HT in the induction groups, but not in the control group. 1 , standard 5-HT group; 2, neuritin group; 3, control group. rBM-MSCs, rat bone marrow-derived mesenchymal stem cells; 5-HT, 5-hydroxytryptamine.

indicated that the NL cells expressed the mature neural marker NSE (26) and the dendritic cell marker MAP2 $(3,27)$, but not the astrocyte marker GFAP (28). These findings demonstrated that the rBM-MSCs treated with neuritin differentiated into the neuronal lineage and not into astrocytes. However, while the cell morphology and the expression of neural-specific markers partially reflected the level of cell differentiation, the functional characterization of the NL cells was the key indicator for evaluating cell differentiation (29). By patch clamp analysis, differences in the $\mathrm{CM}$ and $\mathrm{RP}$ values were detected in the NL cells compared with those of the control. An increased $\mathrm{CM}$ indicates increased surface area of the cell membrane, and is evidence supporting cellular vesicle secretion (30). Notably, the detection of 5-HT secretion by NL cells in the present study is consistent with an increased CM. Furthermore, secretion of this neurotransmitter is an important indicator of neuron function. Meanwhile, the observed decrease in RP denotes that the NL cells exhibited a membrane potential similar to that of mature neurons, thereby confirming that the cells were 
indeed differentiating into the neuronal lineage (31). Finally, the delayed rectifier $\mathrm{K}^{+}$-current recorded by the whole-cell voltage clamp method indicated that the NL cells exhibited the $\mathrm{K}^{+}$properties of neurons. This finding was consistent with the results obtained by physiological analysis of differentiated embryo-derived neural stem cells $(32,33)$.

In conclusion, the present study demonstrated that neuritin-induced MSCs differentiated into NL cells. These cells exhibited typical neuronal morphological features, expression of neuronal markers and secretion of the neurotransmitter 5-HT. Furthermore, these NL cells exhibited partial neural-electrophysiological functions. The results of the present study therefore demonstrated that neuritin is involved in the directional differentiation potential of MSCs into NL cells. Although still in a nascent stage, this novel methodology may provide an alternative, potentially complementary tool for disease modeling and the development of cell-based therapies.

\section{Acknowledgements}

The authors would like to thank Professor Ketao Ma (Shihezi University, Shihezi, China) for the technical assistance with the patch clamp. The present study was supported by the Key Project of Xinjiang Province (grant. no. 2014AB048), the Major Scientific and Technological Innovation Project of Hangzhou (grant. no. 20152013A01) and the Key Project of Shihezi University (grant no. ZRKX2010ZD03).

\section{References}

1. Bjorklund A and Kordower JH: Cell therapy for Parkinson's disease: What next? Mov Disord 28: 110-115, 2013.

2. Freed CR: Will embryonic stem cells be a useful source of dopamine neurons for transplant into patients with Parkinson's disease? Proc Natl Acad Sci USA 99: 1755-1757, 2002.

3. Sanchez C, Díaz-Nido J and Avila J: Phosphorylation of microtubule-associated protein 2 (MAP2) and its relevance for the regulation of the neuronal cytoskeleton function. Prog Neurobiol 61: 133-168, 2000.

4. Lim JY, Park SI, Oh JH, Kim SM, Jeong CH, Jun JA, Lee KS, Oh W, Lee JK and Jeun SS: Brain-derived neurotrophic factor stimulates the neural differentiation of human umbilical cord blood-derived mesenchymal stem cells and survival of differentiated cells through MAPK/ERK and PI3K/Akt-dependent signaling pathways. J Neurosci Res 86: 2168-2178, 2008.

5. Naeve GS, Ramakrishnan M, Kramer R, Hevroni D, Citri Y and Theill LE: Neuritin: A gene induced by neural activity and neurotrophins that promotes neuritogenesis. Proc Natl Acad Sci USA 94: 2648-2653, 1997.

6. Putz U, Harwell C and Nedivi E: Soluble CPG15 expressed during early development rescues cortical progenitors from apoptosis. Nat Neurosci 8: 322-331, 2005

7. Wang X, Liu C, Xu F, Cui L, Tan S, Chen R, Yang L and Huang J: Effects of neuritin on the migration, senescence and proliferation of human bone marrow mesenchymal stem cells. Cell Mol Biol Lett 20: 466-474, 2015.

8. Zhang Y, Zhang S, Xian L, Tang J, Zhu J, Cui L, Li S, Yang L and Huang J: Expression and purification of recombinant human neuritin from Pichia pastoris and a partial analysis of its neurobiological activity in vitro. Appl Microbiol Biotechnol 99: 8035-8043, 2015.

9. Zohar R, Sodek J and McCulloch CA: Characterization of stromal progenitor cells enriched by flow cytometry. Blood 90 : 3471-3481, 1997.

10. Sung JH, Yang HM, Park JB, Choi GS, Joh JW, Kwon CH, Chun JM, Lee SK and Kim SJ: Isolation and characterization of mouse mesenchymal stem cells. Transplant Proc 40: 2649-2654, 2008.
11. Ma KT, Li XZ, Li L, Jiang XW, Chen XY, Liu WD, Zhao L, Zhang ZS and Si JQ: Role of gap junctions in the contractile response to agonists in the mesenteric artery of spontaneously hypertensive rats. Hypertens Res 37: 110-115, 2014.

12. Qin ZH, Qu JM, Xu JF, Zhang J, Summah H, Sai-Yin HX, Chen CM and Yu L: Intrapleural delivery of mesenchymal stem cells: A novel potential treatment for pleural diseases. Acta pharmacol Sin 32: 581-590, 2011.

13. Yang N, Ng YH, Pang ZP, Südhof TC and Wernig M: Induced neuronal cells: How to make and define a neuron. Cell Stem Cell 9: 517-525, 2011.

14. Potter ED, Ling ZD and Carvey PM: Cytokine-induced conversion of mesencephalic-derived progenitor cells into dopamine neurons. Cell Tissue Res 296: 235-246, 1999.

15. Watmuff B, Pouton CW and Haynes JM: In vitro maturation of dopaminergic neurons derived from mouse embryonic stem cells: Implications for transplantation. PLoS One 7: e31999, 2012.

16. Ye L, Fan Z, Yu B, Chang J, Al Hezaimi K, Zhou X, Park NH and Wang CY: Histone demethylases KDM4B and KDM6B promotes osteogenic differentiation of human MSCs. Cell Stem Cell 11: 50-61, 2012.

17. Yang S, Sun HM, Yan JH, Xue H, Wu B, Dong F, Li WS, Ji FQ and Zhou DS: Conditioned medium from human amniotic epithelial cells may induce the differentiation of human umbilical cord blood mesenchymal stem cells into dopaminergic neuron-like cells. J Neurosci Res 91: 978-986, 2013.

18. Smith RK, Werling NJ, Dakin SG, Alam R, Goodship AE and Dudhia J: Beneficial effects of autologous bone marrow-derived mesenchymal stem cells in naturally occurring tendinopathy. PLoS One 8: e75697, 2013.

19. Erices A, Conget $P$ and Minguell JJ: Mesenchymal progenitor cells in human umbilical cord blood. Br J Haematol 109: 235-242, 2000.

20. Vogel W, Grünebach F, Messam CA, Kanz L, Brugger W and Bühring HJ: Heterogeneity among human bone marrow-derived mesenchymal stem cells and neural progenitor cells. Haematologica 88: 126-133, 2003.

21. Pei X: Who is hematopoietic stem cell: CD34+ or CD34-? Int J Hematol 70: 213-215, 1999.

22. Tomita M, Mori T, Maruyama K, Zahir T, Ward M, Umezawa A and Young MJ: A comparison of neural differentiation and retinal transplantation with bone marrow-derived cells and retinal progenitor cells. Stem Cells 24: 2270-2278, 2006.

23. Woodbury D, Schwarz EJ, Prockop DJ and Black IB: Adult rat and human bone marrow stromal cells differentiate into neurons. J Neurosci Res 61: 364-370, 2000.

24. Neuhuber B, Gallo G, Howard L, Kostura L, Mackay A and Fischer I: Reevaluation of in vitro differentiation protocols for bone marrow stromal cells: Disruption of actin cytoskeleton induces rapid morphological changes and mimics neuronal phenotype. J Neurosci Res 77: 192-204, 2004.

25. BarnabéGF,SchwindtTT,Calcagnotto ME,Motta FL, MartinezG Jr, de Oliveira AC, Keim LM, D'Almeida V, Mendez-Otero R and Mello LE: Chemically-induced RAT mesenchymal stem cells adopt molecular properties of neuronal-like cells but do not have basic neuronal functional properties. PLoS One 4: e5222, 2009.

26. Jin K, Mao XO, Batteur S, Sun Y and Greenberg DA: Induction of neuronal markers in bone marrow cells: Differential effects of growth factors and patterns of intracellular expression. Exp Neurol 184: 78-89, 2003.

27. Ladrech S, Lenoir M, Ruel J and Puel JL: Microtubule-associated protein 2 (MAP2) expression during synaptic plasticity in the guinea pig cochlea. Hear Res 186: 85-90, 2003.

28. Messing A and Brenner M: GFAP: Functional implications gleaned from studies of genetically engineered mice. Glia 43: 87-90, 2003.

29. Reh TA: Neural stem cells: Form and function. Nat Neurosci 5: 392-394, 2002

30. Angleson JK and Betz WJ: Monitoring secretion in real time: Capacitance, amperometry and fluorescence compared. Trends Neurosci 20: 281-287, 1997

31. Kohyama J, Abe H, Shimazaki T, Koizumi A, Nakashima K, Gojo S, Taga T, Okano H, Hata $J$ and Umezawa A: Brain from bone: Efficient 'meta-differentiation' of marrow stroma-derived mature osteoblasts to neurons with Noggin or a demethylating agent. Differentiation 68: 235-244, 2001.

32. Ma K, Fox L, Shi G, Shen J, Liu Q, Pappas JD, Cheng J and Qu T: Generation of neural stem cell-like cells from bone marrow-derived human mesenchymal stem cells. Neurol Res 33: 1083-1093, 2011.

33. Risner-Janiczek JR, Ungless MA and Li M: Electrophysiological properties of embryonic stem cell-derived neurons. PLoS One 6: e24169, 2011. 